\title{
Oxidative stability and shelf life of avocado oil extracted cold and hot using discard avocado (Persea americana)
}

\author{
Jhoseline Guillén-Sánchez ${ }^{(\mathbb{D})}$; Luz María Paucar-Menacho*(D) \\ Universidad Nacional del Santa, Facultad de Ingeniería, Departamento de Ingeniería Agroindustrial y Agrónoma, Av. \\ Universitaria s/n, Urb. Bellamar, Nuevo Chimbote, Ancash, Peru.
}

Received August 31, 2019. Accepted March 8, 2020.

\begin{abstract}
During the last years, the world avocado trade is on the rise, however, approximately $20 \%$ of the production is rejected for low caliber. This avocado discarded by low caliber can be used in the elaboration of other products, to give it added value. The objective of this study was to determine the shelf life of Hass avocado oil, type of discard, obtained by: (a) Drying by stove/Soxhlet (b) Lyophilized/Expeller. For the physicochemical characterization of the oil, density, melting point, acidity index, refractive index, iodine index and peroxide index were determined. The induction time was carried out by the RANCIMAT method, for which three temperatures of $1400^{\circ} \mathrm{C}, 160^{\circ} \mathrm{C}$ and $180^{\circ} \mathrm{C}$ were used and the shelf life of the oil was obtained by extrapolation at $25^{\circ} \mathrm{C}$. The results indicate that there is a significant statistical difference in the physicochemical characteristics of both oils. The shelf life was for the oil obtained by drying stove/Soxhlet 5.94 years and for the oil obtained by freeze-dried/Expeller 4.41 years, since both oils had a high content of unsaturated fatty acids $16.98 \%$ and $17.12 \%$, respectively. In conclusion, it is possible to reduce post-harvest losses by obtaining avocado oil with high nutritional and functional qualities.
\end{abstract}

Keywords: avocado oil; lyophilized; soxhlet; unsaturated fatty acid; shelf life.

\section{Introduction}

The fresh avocado has acquired in recent years' great importance in international consumption. Mexico is the world's leading avocado exporter and represents around $45 \%$ of world exports. The second place is occupied by Peru with 179 thousand tons corresponding to $12.7 \%$ of the total. Exports in 2017 totaled 558 million dollars (Koo, 2017), consolidating Peru as one of the main suppliers of avocados to the United States and the European Union (MINAGRI, 2015). Production as the export of avocados is on the rise and brings with it a progressive increase in the volumes of discard type fruit, which is sold in the national markets at lower prices. The industrialization of these remnants becomes an increasingly important alternative for its use. The avocado is raw material rich in oil, so the extraction and production of it can be considered as an interesting option. Avocado oil extracted from ripe fruits has a high oleic acid content, which constitutes a safe and healthy food, in addition to containing vitamin $E$ ( $\alpha$ tocopherol), $10.11 \mathrm{mg} / 100 \mathrm{~g}$, which behaves as a protective agent against oxidation, increasing the shelf life of the product (Nwaokobia et al., 2018, Betancur et al., 2017). The evaluation of the shelf life of vegetable oils is important in the food industry because it ensures the quality and safety with which the product will be distributed. Tests of accelerated storage by static and dynamic methods allow estimating the shelf life of oils. Static methods such as peroxide index allow periodic detection of product oxidation due to oxidation, and dynamic methods such as RANCIMAT measure oxidation induction time, and it is more reliable, reproducible and time-consuming (Aktar and Adal, 2019).

Landeo (2019) used the static method to estimate the shelf life of aguaje (Mauritia flexuosa) oil. The oil was extracted by the press and stored in amber bottles for five days at $45^{\circ} \mathrm{C}, 55^{\circ} \mathrm{C}$ and $65^{\circ} \mathrm{C}$.

The peroxide index was evaluated during the storage days. The Arrhenius mathema-

How to cite this article:

Guillén-Sánchez, J.; Paucar-Menacho, L.M. 2020. Oxidative stability and shelf life of avocado oil extracted cold and hot using discard avocado (Persea americana). Scientia Agropecuaria 11(1): 127-133. 
tical model was used to determine the rate of deterioration of the oil concerning for to temperature, extrapolation was performed at $18^{\circ} \mathrm{C}$. This resulted in 272 days of product shelf life (Iparraguirre, 2019).

Iparraguirre (2019) evaluated the shelf life of sacha inchi oil by the dynamic method. The oil was extracted by cold pressing and subjected to RANCIMAT at $70^{\circ} \mathrm{C}, 80^{\circ} \mathrm{C}, 90$ ${ }^{\circ} \mathrm{C}$ and $100{ }^{\circ} \mathrm{C}$. The results showed that the shelf life of sacha inchi oil was 0.12 years. Another similar study was carried out by Aktar and Adal (2019). Avocado oil was extracted by centrifugation and subjected to RANCIMAT at temperatures of $100^{\circ} \mathrm{C}, 110$ ${ }^{\circ} \mathrm{C}, 120{ }^{\circ} \mathrm{C}, 130{ }^{\circ} \mathrm{C}$ and $140{ }^{\circ} \mathrm{C}$. The results showed that the shelf life of avocado oil was 210 days. The scientific literature presents little information on studies carried out in determining the shelf life of avocado oil, for this reason, the present study was carried out, whose objective was to obtain and physicochemical characterize the Hass avocado oil type discarded by the cold and hot method, to obtain a product with optimal quality conditions and with beneficial components of the Health.

\section{Materials and methods}

In the present investigation, samples of avocado Hass type discarded were donated by the municipality of Cascajal, Ancash-Peru.

\subsection{Extraction of Hass Avocado Oil}

The Hass avocado pulp discarded by lowcaliber was subjected to the extraction of oil by the cold and hot method as shown in Figure 1, respectively.

\subsection{Physicochemical Characteristics}

The chemical characteristics evaluated were: Peroxide index (PI) according to the AOCS method Cd 8-53, Acidity index (Al) according to the method of ISO 660: 2009; lodine index (II) using the Wijs method, following AOAC 993.20 (1995). The physical characteristics evaluated were: Relative Density (RD) using the pycnometer method according to the CODEX, Refraction index (RI) was carried out following the method AOCS-Cc 7-25 (1998). The Rudolph Research brand digital refractometer (Model J157) was used, Melting Point (MP) was carried out following the closed capillary method, regulated by INEN 0474: 1980, and Instrumental Color by the CIELAB method, using a digital colorimeter KONICA MINOLTA (CR-400T). The fatty acids composition was determined according to the Fames method, AOAC 991.39 (2003).

\subsection{Oxidative stability and shelf life of avocado oil}

The determination of the shelf life was carried out using the extrapolation method at the usual storage temperature $\left(25^{\circ} \mathrm{C}\right)$. Each analysis was performed in triplicate, using the equipment Rancimat, Metrohm 743 brand, where $3 \mathrm{~g}$ of the sample was subjected to temperatures of 140,160 and $180^{\circ} \mathrm{C}$ for both types of oils, at a constant airflow of $20 \mathrm{~L} / \mathrm{h}$ (Nakatane et al., 2001).

\subsection{Statics Analyses}

The analyses were performed in triplicate, and the results were treated statistically by calculating means and standard deviations. Analysis of variance (ANOVA) and Tuckey test were performed to compare means in both oils and determine if there are significant differences between the results for each analysis (RD, RI, AI, II, PI, MP and instrumental color) for this the Stat Graphics Centurion software (version 2014, USA) was used. The differences were considered statistically significant at a level of $p<0.05$.

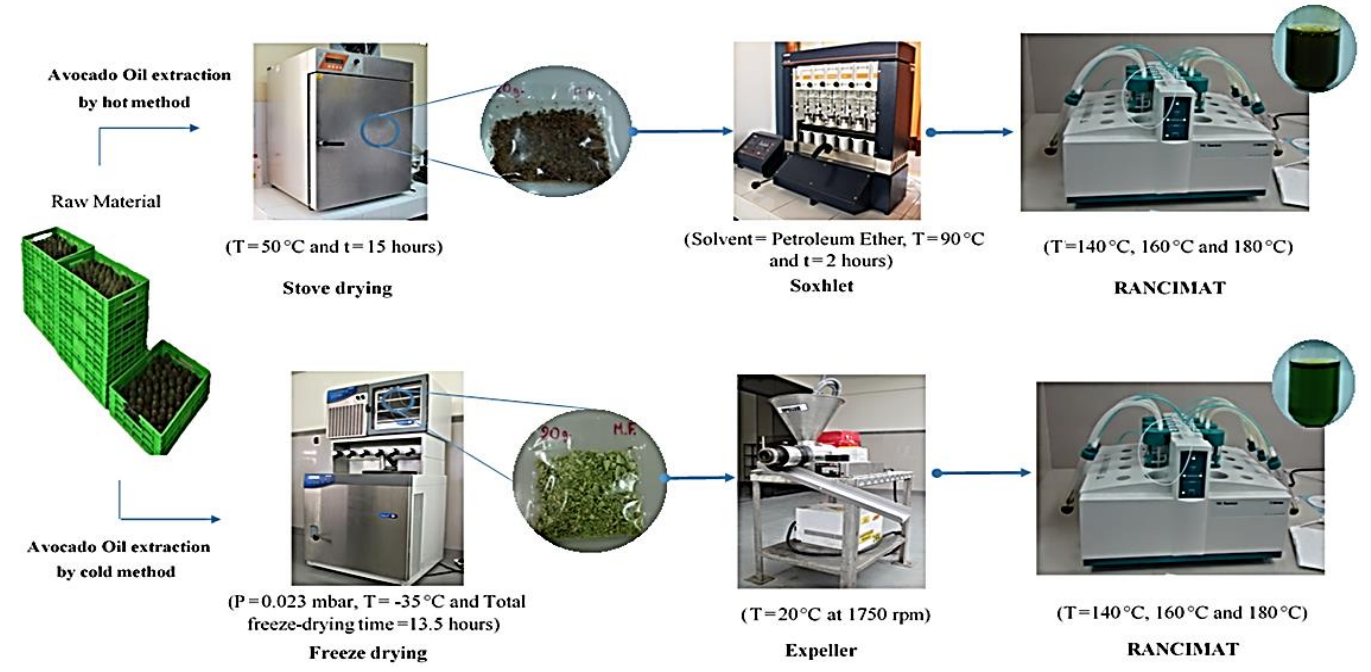

Figure 1. Scheme of extracting avocado oil. 


\section{Results and discussion}

Table 1 shows the results of the physical and chemical characteristics of oils obtained by the cold method (CMO) and by the hot method (HMO), respectively. Except for color, characteristics such as RD, RI, MP, $\mathrm{AI}, \mathrm{PI}$ and II showed statistically significant differences in both treatments.

\subsection{Determination of relative density (RD)}

The value obtained from the HMO, 0.81 (20 ${ }^{\circ} \mathrm{C} /$ water at $20^{\circ} \mathrm{C}$ ), was lower compared to virgin olive oil $(0.91-0.92)$ (Codex Stan $210: 1999)$ while that of the CMO, $0.95\left(20^{\circ} \mathrm{C}\right.$ I water at $20{ }^{\circ} \mathrm{C}$ ), was higher. The value obtained from the CMO was lower compared to virgin olive oil (0.91-0.92) (Codex Stan 210:1999) while that of the HMO was higher. Also, the Mexican technical standard, NMXF-052-SCFI: 2008, indicates values for avocado oil between 0.91 and 0.92 , so both oils are outside the limits established by this technical standard. According to Lewis (1993), density is a parameter that is directly related to molecular weight, and indirect to the degree of unsaturation of the sample. As the CMO presents greater density, it can be inferred that it presents a higher degree of unsaturation than the HMO. This low HMO unsaturation can be due to the thermal degradation suffered by unsatura-ted fatty acids when exposed to high extraction temperatures (Reda, 2011).

\subsection{Refraction index (RI)}

Concerning RI, HMO has a lower value compared to other oils of similar composition, such as olive oil (1.46-1.47 at $20^{\circ} \mathrm{C}$ ) (Codex Stan 210:1999). Similar data were reported in Hass avocado oil obtained using petroleum ether as a solvent by Guzman et al. (2008) and González (2009), these refraction indexes were 1.47 and 1.48, respectively. For oils extracted in cold, the Mexican technical standard, NMX-F-052SCFI: 2008, indicates RI values between $1.45-1.46\left(40^{\circ} \mathrm{C}\right)$ and Guzman et al. (2008)
RI values of $1.47\left(25^{\circ} \mathrm{C}\right)$. The latter was similar to the one obtained in the CMO. The RI values in an oil sample are related to the degree of unsaturation and the Cis/Trans ratio of the double bonds (Gutierrez et al., 2011). Its value can be altered by the oxidation of fatty acids (Hamilton and Rossel, 1987), so it can be inferred that the HMO, having a higher RI value than the CMO, was influenced by the extraction method and that during its measurement the oil had some oxidation of fatty acids.

3.3. Determination of the Melting point (MP) The value obtained from $\mathrm{HMO}, 15^{\circ} \mathrm{C}$, is high compared to virgin olive oil $\left(5^{\circ} \mathrm{C}-12{ }^{\circ} \mathrm{C}\right)$ (Codex Stan, 210:1999) while the CMO, 12 ${ }^{\circ} \mathrm{C}$, shows a value within the range. According to Nwaokobia et al. (2018), the melting points of fatty acids present in an oil increase with the length of the chain and decrease with an increase in the establishment. The presence of impurities in the oil also alters the MP, so this constant constitutes a good criterion of purity.

Unsaturated fatty acids generally have lower melting points than saturated fatty. Therefore, it is inferred that CMO retains a greater amount of unsaturated fatty acids than HMO.

\subsection{Color determination}

In $\mathrm{HMO}$, $\mathrm{a}^{*}$ value, being negative and found between the values of 0 and -10 , shows a tendency to dark green. The value presented by $b^{*}$ shows a tendency to yellow. Both trends to the green and yellow color are typical of avocado oil which makes it very attractive to the eye of the consumer. Reed (2001) concluded that avocado oil, unlike olive oil, has higher levels of chlorophyll, so the oil will always show a tendency to green. As for the chroma, the HMO presented a greater value (46.29) compared to the one obtained in CMO (39.83), although both belong to the second quadrant between the green and yellow tones, the latter has a greener shade than the other.

Table 1

Physical-Chemical characteristics of $\mathrm{HMO}$ and $\mathrm{CMO}$ oils

\begin{tabular}{|c|c|c|c|}
\hline \multirow{2}{*}{ Physical chemical characteristics } & \multirow{2}{*}{ Unit } & \multicolumn{2}{|c|}{ Oils } \\
\hline & & HMO & CMO \\
\hline Relative Density & $20^{\circ} \mathrm{C} /$ water a $20^{\circ} \mathrm{C}$ & $0.81 \pm 0.00^{a}$ & $0.95 \pm 0.00^{b}$ \\
\hline Refraction Index & & $1.44 \pm 0.01 \mathrm{a}$ & $1.47 \pm 0.00 \mathrm{~b}$ \\
\hline Melting Point & ${ }^{\circ} \mathrm{C}$ & $15 \pm 0.00 \mathrm{a}$ & $12 \pm 0.00 \mathrm{~b}$ \\
\hline \multicolumn{4}{|l|}{ Color } \\
\hline $\mathrm{L}$ & & $49.08 \pm 0.03^{a}$ & $48.72 \pm 1.11 \mathrm{a}$ \\
\hline$a^{*}$ & & $-6.12 \pm 0.02 a$ & $-9.92 \pm 1.58 \mathrm{a}$ \\
\hline $\mathbf{b}^{*}$ & & $45.89 \pm 1.02^{a}$ & $38.57 \pm 6.17 \mathrm{a}$ \\
\hline$C^{*}$ & & $46.29 \pm 1.01^{a}$ & $39.83 \pm 6.36^{a}$ \\
\hline$h^{\circ}$ & & $97.60 \pm 0.17 a$ & $104.43 \pm 0.59 b$ \\
\hline Acidity Index & $\mathrm{mg} \mathrm{KOH/g} \mathrm{oil}$ & $0.91 \pm 0.09 a$ & $0.62 \pm 0.07^{b}$ \\
\hline lodine Index & $\mathrm{cg} \mathrm{I}_{2} / \mathrm{g}$ oil & $80.76 \pm 3.11^{a}$ & $106.25 \pm 1.50^{b}$ \\
\hline Peroxide Index & meq de $\mathrm{O}_{2} / \mathrm{kg}$ & $19.18 \pm 0.21 \mathrm{a}$ & $10.45 \pm 0.75^{b}$ \\
\hline
\end{tabular}


According to Muños-López et al. (2018) chroma may increase during the lyophilization process of the plant material and consequently in the final product. This indicates the concentration of chlorophyll and other pigments contained in the avocado, compared with samples dried with collective heat. Concerning for to the brightness values and chroma in CMO, they showed values of less than 48.72 and 39.82 , respectively. The mean value of $a^{*}$ was 9.92, which shows a tendency to the green color and the value of $b^{*}$ to the yellow color resulting similar to the oil obtained by the hot method. The hue angle $\left(h^{\circ}\right)$ was greater (104.43), which corresponds to a green color than that obtained by the hot method. According to Badui (2006), the color of the food is due to different compounds, mainly organic or natural pigments that when subjected to thermal treatments generate shades ranging from a light yellow to an intense coffee, through the Maillard reaction (Braverman, 1988; Yaylayan, 1990) and caramelization, on other occasions, the pigments they contain change and change color.

\subsection{Acidity index (Al)}

The acidity results of the CMO $(0.91 \pm 0.09$ oleic acid $\mathrm{mg} \mathrm{KOH} / \mathrm{g}$ oil) are similar to those reported by the CODEX STAN 210: 1999, for olive oil ( 0.3 - 0.6 oleic acid $\mathrm{mg} \mathrm{KOH} \mathrm{/} \mathrm{g} \mathrm{oil)}$ while the HMO shows a value outside the range. For the Mexican technical standard, NMX-F-052-SCFI: 2008, the acidity obtained by both oils is within the established range ( $0.1-1.5$ oleic acid $\mathrm{mg} \mathrm{KOH} / \mathrm{g}$ oil) as well as the Brazilian legislation that allows a maximum acid value of $4.0 \mathrm{mg} \mathrm{KOH} / \mathrm{g}$ for any type of vegetable oil obtained by pressing (ANVISA, 2005). Peruvian legislation does not have any specific regulations for avocado oil. The comparison of the $\mathrm{Al}$ between both samples of oils, the HMO presented greater value than the CMO that can be due to the alteration in the concentration of hydrogen ions, due to an initial process of decomposition (Instituto Adolfo Lutz, 2008) as the hydrolytic rancidity that causes the release of fatty acids (Badui, 2006).

3.6. lodine index (II)

For II, the result obtained from the HMO was similar to that obtained by Restrepo et al.
(2002) that reported values of $77.85 \mathrm{cg} \mathrm{l} / 2 / \mathrm{g}$ oil using hexane as solvent. Also, the value obtained is within the maximum limit established by the Mexican Technical Standard, NMX-F-052-SCFI: $2008,80-90 \mathrm{~g} \mathrm{I}_{2} / \mathrm{g}$ oil. The higher the iodine index, the lower the presence of saturated fatty acids (Calabrese, 1992) since it is a measure of the state of non-saturation of lipids. According to the above, the CMO preserves the greater amount of unsaturated fatty acids as opposed to $\mathrm{HMO}$ as well as a greater predisposetion to present oxidative reactions that deteriorate the oil (Jimenez et al., 2011).

\subsection{Peroxide index (PI)}

Concerning for to the PI, both oils obtained a value within the range established by CODEX STAN 210: 1999, for virgin olive oil ( $\leq$ 20 meq de $\mathrm{O}_{2} / \mathrm{kg}$ ). However, according to the Mexican Technical Standard, NMX-F052-SCFI: 2008, avocado oil should have a maximum value of $10 \mathrm{meq}$ de $\mathrm{O}_{2} / \mathrm{kg}$ compared to the values obtained, these were relatively higher (CMO: 10.45 and HMO: $19.18 \mathrm{meq}$ de $\mathrm{O}_{2} / \mathrm{kg}$ ). The PI values close to 10 presented by both oil samples may be due to the high degree of unsaturation that avocado oil presents, which influence the speed of oxidation since the unsaturated fatty acids when they are free are oxidized in general faster than saturated fatty acids (Velasco et al., 2004).

Saturated fatty acids are only oxidized at temperatures above $60^{\circ} \mathrm{C}$, while polyunsaturated acids are oxidized even during the storage of frozen food (Martinez, 2008).

\subsection{Fatty acids composition}

Table 2 shows the results of the fatty acid composition of oils obtained by the cold method (CMO) and by the hot method (HMO), respectively.

The HMO consists mostly of saturated fatty acids, while the CMO consists mostly of unsaturated fatty acids. In the case of $\mathrm{HMO}$, oleic acid (18: $1 \mathrm{w} 9$ ) represents more than $35 \%$ of the totality while the arachidonic acid (20: 4 w6) reaches $20 \%$. The $\mathrm{CMO}$ is made up mostly of oleic acid, more than $40 \%$, while the arachidonic acid is less than $20 \%$. Saturated fatty acids are present in both oils in a very similar proportion to that of unsaturated fatty acids.

Table 2

Fatty acid Composition of HMO and CMO oils

\begin{tabular}{lcccc}
\hline Type of Fatty Acids & Fatty Acid & Unit & Concentration (HMO) & Concentration $(C M O)$ \\
\hline Saturated & Palmitic Acid & $\%(\mathrm{~g} / 100 \mathrm{~g})$ & 28.4 & 26.45 \\
Unsaturated & Heptadecanoic Acid & $\%(\mathrm{~g} / 100 \mathrm{~g})$ & 14.43 & 13.58 \\
Poly Unsaturated & Oleic Acid & $\%(\mathrm{~g} / 100 \mathrm{~g})$ & 39.73 & 42.99 \\
\hline
\end{tabular}


Olaeta et al. (1999) report that oleic acid varies between 48.4 and $66.8 \%$ for avocado oil Hass variety, this value is close to that obtained by Human (1987), which indicates that the relative percentage of oleic acid in avocado Hass, is around $70.5 \%$. The concentration of oleic acid obtained in the present investigation was $39.73 \%$. These obtained concentrations can be attributed to the state of development of the fruit, which influences the variation of the lipid content (Pérez et al., 2005).

The second most important acid is arachidonic acid. The CMO presents high levels of polyunsaturated fatty acids $(16.99 \%)$ unlike olive oil $(10.66 \%)$, but lower than sunflower oil (61.39\%) (Blanco et al., 2006).

The arachidonic acid has twenty carbons in its structure and belongs to the family of $\omega$ 6; according to Valenzuela et al. (2011) these compounds play critical roles in the structure of cell membranes and the immune system of the human body, so they are essential for the body and should be included in the diet.

There was no presence of linolenic acid in the avocado oils obtained (Table 2); according to Mataix and Gil (2002), the avocado oil contains a low amount of this unsaturated acid.

\subsection{Shelf Life of avocado oil}

Table 3 shows the shelf life of avocado oil (HMO and CMO) estimated at $25^{\circ} \mathrm{C}$ by extrapolation (Figures $2 a$ and $2 b$ ), as well as the comparison with other vegetable oils.

The shelf life of CMO was relatively shorter, compared to the HMO, due to the high degree of chemical reactivity presented by its unsaturation. When comparing the results with those obtained in other vegetable oils (Table 3 ), it can be observed that the avocado oil had a longer shelf life than the sacha inchi, Mauritia flexuosa oil and cottonseed oils. This difference can be attributed to the higher percentage of polyunsaturated acids present in

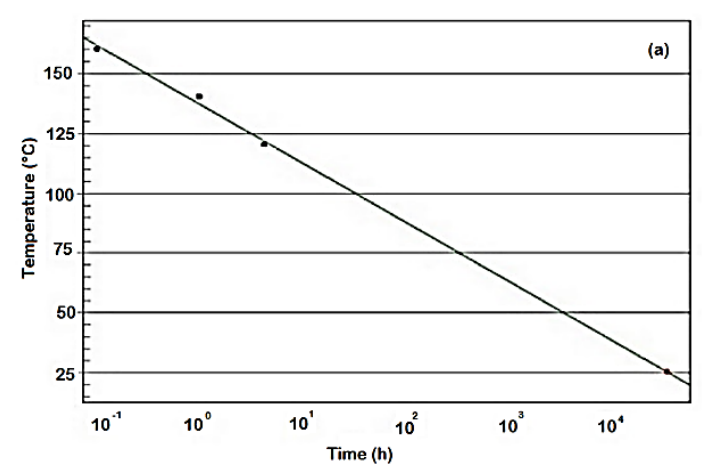

Figure 2. (a) Extrapolation at $25^{\circ} \mathrm{C}$ of the shelf life of the HMO. (b) Extrapolation at $25^{\circ} \mathrm{C}$ of the shelf life of the CMO. cottonseed and sacha inchi oils, which are 41.6\% (Alemayhu et al., 2019) and 33.9\% (Castaño et al., 2012), respectively, while the avocado oil (CMO) extracted in the present study obtained approximately $17 \%$. According to Landeo (2019), polyunsaturated fatty acids are less stable than monounsaturated acids due to the presence of more than two unsaturation, which makes oxygen easily absorbed by the oils.

Table 3

Shelf life of HMO and CMO oils, and its comparison with other vegetable oils

\begin{tabular}{|c|c|c|c|}
\hline Sample & $\begin{array}{c}\text { Shelf } \\
\text { life } \\
\text { (years) }\end{array}$ & Method & References \\
\hline HMO oil & 5.94 & Rancimat & This research \\
\hline CMO oil & 4.41 & Rancimat & This research \\
\hline Olive oil & 1.85 & Rancimat & $\begin{array}{c}\text { Farhoosh et } \\
\text { al. (2013) }\end{array}$ \\
\hline Peanut oil & 0.87 & $\begin{array}{l}\text { Peroxide } \\
\text { analysis }\end{array}$ & $\begin{array}{c}\text { Alemayhu et } \\
\text { al. (2019) }\end{array}$ \\
\hline $\begin{array}{l}\text { Cottonseed } \\
\text { oil }\end{array}$ & 0.78 & $\begin{array}{l}\text { Peroxide } \\
\text { analysis }\end{array}$ & $\begin{array}{c}\text { Alemayhu et } \\
\text { al. (2019) }\end{array}$ \\
\hline $\begin{array}{l}\text { Mauritia } \\
\text { flexuosa oil }\end{array}$ & 0.74 & $\begin{array}{l}\text { Peroxide } \\
\text { analysis }\end{array}$ & $\begin{array}{l}\text { Landeo } \\
\text { (2019) }\end{array}$ \\
\hline $\begin{array}{l}\text { Sacha } \\
\text { Inchi oil }\end{array}$ & 0.25 & $\begin{array}{l}\text { Peroxide } \\
\text { analysis }\end{array}$ & $\begin{array}{c}\text { Iparraguirre } \\
\text { (2019) }\end{array}$ \\
\hline
\end{tabular}

Olive oil and peanut oil have lower polyunsaturated content but higher monounsaturated content than sacha inchi oil and cottonseed oil, $56.82 \%$ and $46.2 \%$, respectively (Alemayhu et al., 2019). The avocado oil obtained in the present study showed $42.9 \%$ of unsaturated fatty acids and $40.3 \%$ of saturated fatty acids, presenting greater stability than the vegetable oils mentioned above and therefore a longer shelf life.

According to Zambrano-Herrera et al. (2017), the PI in an oil sample decreases the shelf life of the oil. However, the values obtained from IP and shelf life do not show a direct relationship. This, probably at Rancimat oxidation that generates an immediate appearance of primary and secondary compounds that cannot be fully detected by a peroxide analysis (Rodriguez et al., 2015).

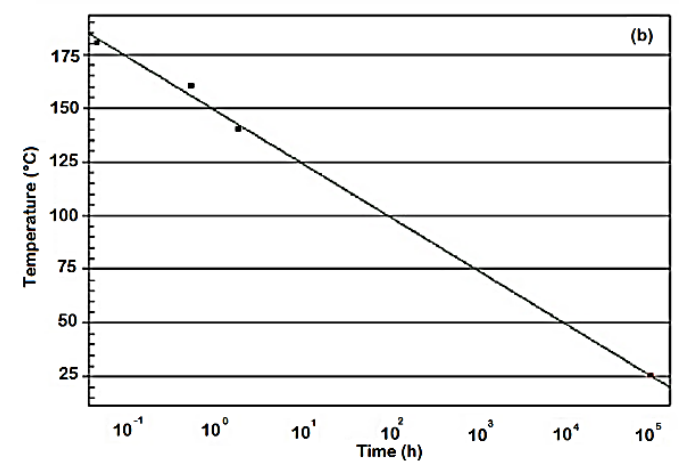


The shelf life of an oil decreases during storage due to the degradation of its compounds that can be due to factors such as light, temperature, presence of oxygen and the high amount of unsaturated fatty acids. Oxidations are mainly carried out in these fatty acids than in saturated oils that are oxidized from $60^{\circ} \mathrm{C}$ and polyunsaturated oils that are oxidized even when frozen (Pereyra et al., 2009).

\section{Conclusions}

Four fatty acids were found for both HMO and CMO; however, the CMO showed a lower percentage of saturated fatty acids and a higher percentage of unsaturated fatty acids, especially oleic acid, than the HMO. The convenient ingestion of this unsaturated fatty acid provides healthy characteristics for the human being.

The Shelf life, measured as a function of the oxidative rancidity, of the CMO was 4 years while that of the HMO was 5 years, inferring a high antioxidant capacity and high stability. The physicochemical characteristics of the CMO as acidity index, melting point and refractive index are within the acceptable ranges according to the international food standards for vegetable oils and the Mexican technical standards for avocado oil. In the HMO, only the acidity index is within these ranges.

\section{Acknowledgements}

To the Municipalidad de Cascajal, Ancash, Peru for the donation of avocado Hass type discard and to the Institute of Agroindustrial technology research (IITA) of the Universidad Nacional del Santa, that facilitated its environments for carrying out the present investigation.

\section{ORCID}

J. Guillén-Sánchez iD https://orcid.org/0000-0002-0899-6725 L.M. Paucar-Menacho (D) https://orcid.org/0000-0001-5349-6167

\section{References}

AOAC 991.39. 2003. Fatty Acids in Encapsulated Fish Oils and Fish Oil Methyl and Ethyl Esters. Official Methods of Analysis of American Official Agricultural Chemists.

AOCS Cc 7-25. 1998. Sampling and analysis of commercial fats and oils, Refractive Index. 5th Edition. Official methods and recommended practices of the American oil chemists' society. Champaign.

AOAC 993.20.1995. lodine Value of Fats and Oils. Official methods of analysis of American official agricultural chemists. 19th Edition. Champaign.

Aktar, T.; Adal, E. 2019. Determining the Arrhenius Kinetics of Avocado Oil: Oxidative Stability under Rancimat Test Conditions. Foods 8(7): 236-266.
Alemayhu, A.; Admassu, S.; Tesfaye, B. 2019. Shelf-life prediction of edible cotton, peanut and soybean seed oils using an empirical model based on standard quality tests, Cogent Food \& Agriculture 5(1): 1-18.

ANVISA - Agencia Nacional de vigilância sanitária. 2005. Regulamento técnico para óleos vegetais, gorduras vegetais e creme vegetal, Resolução RDC $n^{\circ} 270$, de 22 de setembro de 2005. Diário Oficial [da] República Federativa do Brasil, Brasília, DF, 23 dez. 2005. Sección 1, p. 373.

Asociación de Normas Técnicas Mexicanas. 2008. NMXF-052-SCFI-2008: Aceite de Aguacate especificaciones. México, $12 \mathrm{pp}$.

Badui, S. 2006. Química de los Alimentos. 4th Edition. Editorial Pearson Educación. Mexico. 738 pp.

Betancur, D; Sanchez, L.; Marquez, C. 2017. Extracción termomecánica y caracterización fisicoquímica del aceite de aguacate (Persea americana Mill. cv. Hass). Informador Técnico 81(1): 75-85.

Blanco, N.; López, M.; López, M. 2006. Vida útil del aceite de girasol Alto Oleico y del aceite de girasol convencional durante el proceso continuo de fritura de maní. Tesis de pregrado. Universidad Nacional de Córdoba, Argentina. 47 pp.

Braverman, J.B.S. 1988. Introducción a la Bioquímica de Ios Alimentos. Editorial El Manual Moderno S.A. Barcelona, España. Pp. 167-218.

Calabrese, F. 1992. El aguacate. Editorial Mundi-Prensa S.A., Madrid, España. 243 pp.

Castaño, D.; Valencia, M.; Murillo, E.; Mendez, J.; Eras, J. 2012. Composición de ácidos grasos de sacha inchi (Plukenetia volúbilis Linneo) y su relación con la bioactividad del vegetal. Revista chilena de nutrición 39(1): 45-52.

CODEX STAN. 1999. 210-1999: Norma para aceites vegetales especificados. Lima, Perú, 14 pp.

Farhoosh, R.; Hoseini-Yazdi, S. 2013. Shelf-life prediction of olive oils using empirical models developed at low and high temperatures. Food Chemistry 141: 557565.

González, R. 2009 cited by Castañeda-Antonio, D.; Lopez-Varela, P.; Guel-Silva, G.; Ramos-Cassellis, E.; Ariza-Ortega, A.; Carrera-Martinez, C.D.; PortilloReyes, R. Caracterización oxidativa de aceite de aguacate Hass y aceites de aguacate criollo (Persea americana Mill. Var. Drymifolia). En Proceedings of Congreso Mundial de la Palta, Lima. Pp. 423-429.

Gutiérrez, L.; Rosada, L.; Jiménez, A. 2011. Chemical composition of Sacha Inchi (Plukenetia volúbilis L.) seeds and characteristics of their lipid fraction. Grasas y aceites 62: 76-83.

Guzman, R.I.; Lopez, M.G.; Dorantes, L. 2008. Microwave processing of avocado: Volatile flavor profiling and olfactometry. Innovative Food Science Emerging Technologies 9(4): 501-506.

Hamilton, R.J.; Rossell, J. B. 1987. Analysis of oils and fats. Editorial Elsevier Applied Science Publishers. Londres, Inglaterra.

Human, T. 1987. Oil as a byproduct of the avocado. South African Avocado Growers' Association Yearbook 10: 159-162.

Instituto Adolfo Lutz. 2008. Óleos e gorduras. In: Zenebon, O.; Pascuet, N.S.; Tiglea, P. Métodos físico-químicos para análise de alimentos. 4th Edition. Edit. Inst. Adolfo Lutz. Brazil. Pp. 525-629.

Instituto Ecuatoriano De Normalización. 1980. INEN 0474-1980: Determinación del punto de fusión. Ecuador. 9 pp.

Iparraguirre, K. 2019. Contribución al estudio de la vida útil de los aceites de sacha inchi (Plukenetia huayllabambana y $P$. volubilis) microencapsulados y su importancia en la industria alimentaria. Universidad de Lima, Perú. 175 pp.

Jiménez, M.; Aguilar, M.R.; Zambrano, M.L.; Kolar, E. 2001. Propiedades fisicoquímicas del aceite de aguacate obtenido del puré deshidratado por microondas. Revista de la Sociedad Química de México 45(2): 89-92. 
Koo, W. 2017. Aguacate - Paltas Perú Exportación 2017 Noviembre. Agrodataperu. Available in: https://www.agrodataperu.com/2017/12/exportacio n-aguacate-paltas-peru-exportacion-2017noviembre.html.

Landeo, E. 2019. Vida útil del aceite de aguaje (Mauritia flexuosa L.F.) mediante pruebas aceleradas. Tesis de maestría. Universidad Nacional del Callao, Lima, $102 \mathrm{pp}$.

Lewis, M.J. 1993. Propiedades físicas de los alimentos y de los sistemas de procesado. Editorial Acribia S.A. Zaragosa, España. 514 pp.

Martinez, J.L. 2008. Supercritical fluid extraction of nutraceuticals and bioactive compounds. Editorial Taylor \& Francis Group. New York, USA. 440 pp.

Mataix, J.; Gil, A. 2002. Lípidos Alimentarios. In: Instituto Omega. Libro Blanco de los Omega-3: Los ácidos grasos poli insaturados omega-3 y mono insaturados tipo oleico y su papel en la salud. Editorial Puleva. Granada, España. Pp. 13-33.

MINAGRI - Ministerio de Agricultura y Riego. 2015. La Palta: Producto estrella de exportación, tendencias de la producción y el comercio de palta en el mercado internacional y nacional. Dirección General de Políticas Agrarias del Ministerio de Agricultura y Riego.

Muñoz-López, C.; Urrea-García, G.; Jiménez-Fernández, M.; Rodríguez-Jiménes, G.C.; Luna-Solano, G. 2018. Efecto de las condiciones de liofilización en propiedades fisicoquímicas, contenido de pectina y capacidad de rehidratación de rodajas de ciruela (Spondias purpurea L.). Agrociencia 52(1): 1-13.

Nakatane, N.; Tachibana, Y.; Kikuzaki, H. 2001. Establishment of model substrate oil for antioxidant activity assessment by oil stability index method. Journal of the American Oil Chemists Society 78: 1923.

Nwaokobia, K.; Ogboru, R.O.; Idibie, C.A. 2018. Extraction of edible oil from the pulp of Persea Americana Mill using cold process method. World News of Natural Sciences 17: 130-140.

Olaeta, J.; Undurraga, P.Y.; Schwartz, M. 1999. Determinación de la evolución y caracterización de los aceites en palta, Persea Americana cv. Fuerte y
Hass cultivados en Chile. Revista Chapingo Serie Horticultura 5: 117-122.

Organization International of Normalization. 2009. ISO 660:2009 Animal and vegetable fats and oils: Determination of acid value and acidity. 3 rd Ed. 9 pp.

Pereyra, M.; Boque, D.; Costamagna, D.; Rodriguez, P.; Speltini, C.; Coppo, G. 2009. Auto oxidación de aceites vegetales comerciales. Revista Rumbos Tecnológicos 1(1): 53-63.

Pérez, R.; Villanueva, S.; Cosío, R. 2005. El aceite de aguacate y sus propiedades nutricional. e-Gnosis 10(3): 2-11.

Reda, S.Y. 2011. Avaliação da estabilidade de antioxidantes por análise térmica e seu efeito protetor em óleo vegetal aquecido. Ciência e Tecnologia de Alimentos 31(2): 475-80.

Reed, I. 2001. Avocados: The new wonder oil. Food New Zealand 31(1): 20-25.

Restrepo, A.M.; Londoño, J.; González, D; Benavides, Y.; Cardona, B. 2002. Comparación del aceite de aguacate variedad Hass cultivado en Colombia, obtenido por fluidos supercríticos y métodos convencionales: una perspectiva desde la calidad. Revista Lasallista de Investigación 9(2): 151-161.

Rodríguez, G.; Villanueva, E.; Glorio, P.; Baquerizo, M. 2015. Estabilidad oxidativa y estimación de la vida útil del aceite de sacha inchi (Plukenetia volubilis L.) Scientia Agropecuaria 6(3): 155-163.

Valenzuela, R.; Tapia, G.; González, M.; Valenzuela, A. 2011. Omega-3 Fatty Acids (EPA and DHA) and its Application in Diverse Clinical Situations. Revista Chilena de Nutrición 38(3): 356-367.

Velasco, J.; Marmesat, S.; Márquez-Ruiz, G.; Dobarganes, M.C. 2004. Formation of short-chain glycerol-bound oxidation products and oxidized monomeric triacylglycerol during deep-frying and occurrence in used frying fats. European Journal of Lipid Science and Technology 106: 728-735.

Yaylayan, V. 1990. In search of alternative mechanisms for the Maillard reaction. Trends in Food Science and Technology 1: 21-22.

Zambrano-Herrera, W.; Martínez, J.; Fernández, J. 2017. Determinación de la vida útil de la grasa de semilla de mango a diferentes temperaturas de almacenamiento. Revista Agrollanía 14: 1-5. 